\title{
MATHEMATICAL MODELING OF ORANGE SEED DRYING KINETICS
}

\author{
Modelagem matemática da cinética de secagem de semente de laranja
}

\author{
Daniele Penteado Rosa ${ }^{1}$, Denis Cantú-Lozano ${ }^{2}$, Guadalupe Luna-Solano ${ }^{2}$, \\ Tiago Carregari Polachini ${ }^{3}$, Javier Telis-Romero ${ }^{3}$
}

\begin{abstract}
Drying of orange seeds representing waste products from juice processing was studied in the temperatures of 40, 50, 60 and $70{ }^{\circ} \mathrm{C}$ and drying velocities of $0.6,1.0$ and $1.4 \mathrm{~m} / \mathrm{s}$. Experimental drying kinetics of orange seeds were obtained using a convective air forced dryer. Three thin-layer models: Page model, Lewis model, and the Henderson-Pabis model and the diffusive model were used to predict the drying curves. The Henderson-Pabis and the diffusive models show the best fitting performance and statistical evaluations. Moreover, the temperature dependence on the effective diffusivity followed an Arrhenius relationship, and the activation energies ranging from 16.174 to $16.842 \mathrm{~kJ} / \mathrm{mol}$.
\end{abstract}

Index terms: Dehydration; diffusive model; Henderson-Pabis model; moisture content.

\section{RESUMO}

A secagem de sementes de laranja que representam produtos residuais do processamento de suco foi estudada nas temperaturas de 40, 50, 60 e $70{ }^{\circ} \mathrm{C}$ e velocidades de secagem de 0,6,1,0 e 1,4 m/s. As cinéticas de secagem experimental de sementes de laranja foram obtidas utilizando um secador de ar forçado por convecção. Três modelos de camada fina: modelo de Page, modelo Lewis, e o modelo de Henderson-Pabis e o modelo difusivo foram utilizados para prever as curvas de secagem. Os modelos de HendersonPabis e difusivo mostraram o melhor desempenho adequado e avaliações estatísticas. Além disso, a dependência da temperatura na difusividade efetiva seguida a relação de Arrhenius, e as energias de ativação variam entre 16,174-16,842 kJ / mol.

Termos de indexação: Desidratação; modelo difuso; modelo Henderson-Pabis; teor de umidade.

\section{INTRODUCTION}

Orange oil is one of the good vegetable oils that have been developed rapidly in many parts of world such as Brazil. The orange seed oil has high amounts of unsaturated fatty acids $(69 \%)$ and essential fatty acids (linoleic + linolenic). Linoleic acid is the major fatty acid present $(38.4 \%)$, followed by oleic $(26.0 \%)$, palmitic (29.5\%), and stearic acids (5.3\%) (El-Adawy; Taha, 2001). The high temperatures and long drying periods of seeds may have deleterious effects on the quality of the oil obtained from the seeds. Careful control of moisture is critical for quality assurance of dry foods during storage. For safe storage, the moisture content of the harvested orange oil seeds needs to be reduced to less than $8 \%$ in dry basis (Doijode, 2001).

Convective drying is a widely used technology and adequate for sub-products, as it is usually employed with dehydration of fruits and vegetables. Drying is a complex process in which simultaneous heat and mass transfer phenomena contribute to moisture removal leading to substantial reduction in mass and volume product minimizing packaging, storage and transportation costs (Vega-Gálvez et al., 2010). Modeling of drying process brings mathematical as well as physical insight into the process; many studies have been devoted to analyzing the different aspects of this phenomenon. The principle of modeling is based on having a set of mathematical equations that can adequately characterize the system. A 'good' drying model should be simple, accurate, robust and able to capture major physics during drying; at the same time the model should require short computational time, favorable for quick decision-making in industry (Barati; Esfahani, 2011). Since knowledge of the moisture distribution inside the solid during ripening is of vital importance for the control of the process and the quality of the product, mathematical models to predict moisture

${ }^{1}$ Universidade Estadual Paulista "Júlio de Mesquita Filho"/UNESP - Departamento de Engenharia e Tecnologia de Alimentos - Rua Cristóvão Colombo - 2265 - Jardim Nazareth - 15054-000 - São José do Rio Preto - SP - Brasil - dani_penteadorosa@yahoo.com.br

${ }^{2}$ Instituto Tecnologico de Orizaba - Division de Estudios de Posgrado e Investigación - Orizaba - México

3Universidade Estadual Paulista "Júlio de Mesquita Filho"/UNESP - Departamento de Engenharia e Tecnologia de Alimentos - São José do Rio Preto - SP - Brasil

Received in february 23, 2015 and approved march 24, 2015 
distribution during drying have been proposed. Thus, the aims of this research were to formulate and validate a mathematical model representative of orange seeds in a thin-layer drier.

\section{MATERIAL AND METHODS}

\section{Raw material and sample preparation}

Orange seeds (C. sinensis cv. Brazilians) used to the experimental procedures were obtained directly from fruit juice production lines of industries in São José do Rio Preto, SP, Brazil. The seeds were manually separated from the waste and washed with distilled water to remove the remaining pomace. The raw material was stored at $5{ }^{\circ} \mathrm{C}$ prior to analysis.

\section{Experimental drying kinetics}

A pilot scale convective dryer (Figure 1) provided with three sections i.e., an airflow rate control system, a drying air heating section, and a drying chamber was used to determine the drying kinetic of orange seeds. The drier was equipped with a process control system based on Fieldbus technology (SMAR Industrial Equipment Ltda., Sertãozinho, Brazil). The dryer was previously described elsewhere (Nicoleti; Telis-Romero; Telis, 2001).

Drying of orange seeds was carried according to the method Cantu-Lozano et al. (2103), using temperatures of $40,50,60$ and $70{ }^{\circ} \mathrm{C}$ and air dry velocities of $0.6,1.0$ and $1.4 \mathrm{~m} / \mathrm{s}$. Temperatures were chosen carefully to avoid damages to the oil in orange seeds. Drying was stopped when the weight of the test sample reached a constant value. Moisture contents at each time interval was calculated in dry basis (d.b.) from both weight loss data and dry solid weight of the sample, determined at the beginning of drying by vacuum oven according to the AOAC 934.06 method (Association Of Analytical Communities - AOAC, 1997). At the end of each test, the relative humidity $(R H)$ was recorded to calculate the water activity $\left(a_{w}\right)$ through the relationship $a_{w}=R H / 100$.

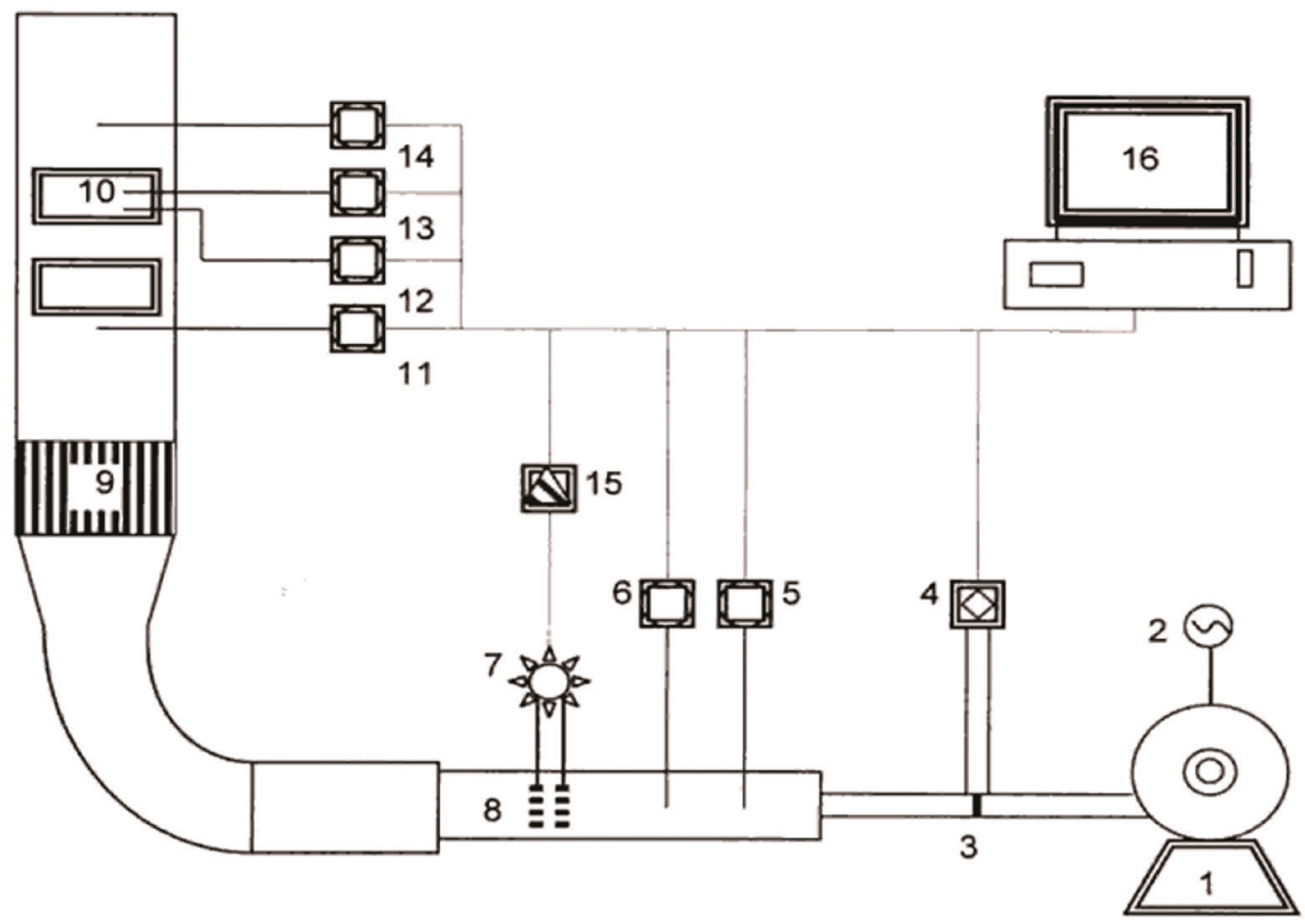

Figure 1: Schematic diagram of the drying equipment. (1) Centrifugal fan. (2) Frequency modulator. (3) Orifice plate. (4) Pressure transmitter. (5,6) Dry and wet bulb temperature transmitters. (7) Power converter. (8) Electric resistances. (9) Honeycomb. (10) Drying compartment. (11,14) Air temperature transmitters. (12) Inner product temperature transmitter. (13) Surface product temperature transmitter. (15) 4 to $20 \mathrm{~mA}$ current converter. (16) Computer. 


\section{Drying kinetic modeling and statistical analysis}

Experimental drying curves of orange seeds were modeled using the thin-layer models of Page (Equation 1), Lewis (Equation 2), and the Henderson-Pabis model (Equation 3).

$M=\frac{x-x_{e}}{x_{i}-x_{e}}=\exp \left(-k t^{\beta_{l}}\right)$

$M=\frac{x-x_{e}}{x_{i}-x_{e}}=\exp (-k t)$

$M=\frac{x-x_{e}}{x_{i}-x_{e}}=\beta_{2} \exp (-k t)$

where $M$ represents the unaccomplished moisture content or moisture ratio (dimensionless), $x$ is the moisture at any time $(t, \mathrm{~s})$ during drying $(\mathrm{kg} / \mathrm{kg}, \mathrm{d} . \mathrm{b}),. x_{i}$ is the initial moisture content $(\mathrm{kg} / \mathrm{kg}$, d.b. $), x_{e}$ is the equilibrium moisture content $(\mathrm{kg} / \mathrm{kg}, \mathrm{d} . \mathrm{b}$.), $k$ is the drying rate constant $(1 / \mathrm{s})$ and $\beta_{1}$ and $\beta_{2}$ are the constants (dimensionless) (Kaleemullah; Kailappan, 2006; Roberts; Kidd; PadillaZakour, 2008). The equilibrium moisture content $\left(x_{e}\right)$ was calculated from the fitting sorption isotherm values through the Oswin model (Equation 4) (corrected values) (Rosa; Villa-Vélez; Telis-Romero, 2013).

$x_{e}=\left(0.169-4.346 \times 10^{-4} T\right)\left(\frac{a_{w}}{1-a_{w}}\right)^{1 / 2.668}$

where $a_{w}$ is the water activity (dimensionless).

Also, the diffusive model (Equation 5) was used to describe the mass transport during the drying process (Sablani; Rahman; Al-Habsi, 2000; Brovchenko; Oleinikova, 2008).

$\frac{\partial M}{\partial t}=\nabla\left|D_{\text {eff }}(\nabla M)\right|$

where $D_{\text {eff }}$ is the effective moisture diffusivity representing the conductive term of all moisture transfer mechanism $(\mathrm{m} /$ $\mathrm{s}^{2}$ ). Based on the assumptions of uniform initial moisture distribution, negligible external, negligible temperature gradients, negligible shrinkage during drying and constant diffusion coefficient, the Equation 5 can be solved using the analytical solution for spherical geometry (Crank, 1975), as followed (Equation 6):

$M=\frac{x-x_{e}}{x_{i}-x_{e}}=6 \sum_{n=1}^{\infty} \frac{1}{n^{2} \pi^{2}} \exp \left(n^{2} \pi^{2} \frac{D_{e f f} t}{r^{2}}\right)$

where $n$ is the number of terms in the series and $r$ is the equivalent radius of the material $\left(\mathrm{m}^{2}\right)$.

The effective moisture diffusivity (Equation 7) can be related with the temperature by the Arrhenius relationship:

$D_{e f f}=D_{0} \exp \left(\frac{-E_{a}}{R T}\right)$

where $D_{0}$ is the pre-exponential factor of the Arrhenius equation $\left(\mathrm{m}^{2} / \mathrm{s}\right), E a$ is the activation energy $(\mathrm{kJ} / \mathrm{mol})$, $R$ is the universal gas constant $\left(8.314 \times 10^{-3} \mathrm{~kJ} / \mathrm{mol} \mathrm{K}\right)$ and $T$ is the absolute air dry temperature $(\mathrm{K})$ (Lopez et al., 2000).

Non-linear regression analysis of the empirical and theoretical drying kinetic models were carried out using the "nlinfit" and "nlparci" function of the Statistic Toolbox of Matlab® ${ }^{\circledR} .1$ (The MathWorks Inc., Natick, MA, USA) considering the robust fitting option. Also, the "lillietest" function was used to determine, if the residuals followed a normal distribution. The adjusted coefficient of determination $\left(R_{a d j}^{2}\right)$ and the mean relative error $(M R E)$ were used to evaluate the goodness of fit and accuracy of the estimation, respectively. The statistical term $R_{a d j}^{2}$ (Equation 8), also known as the explained variation, adjusts the coefficient of determination based on the number of model parameters, and is the criterion that defines how successful the model is in explaining the variation of the experimental data. Thus it is a good indicator of the quality of fit when one compares models that have different numbers of fitted coefficients. In addition, the MRE (Equation 9) was the criterion used to evaluate the accuracy of the estimations. A model with a value for $M R E$ below $15 \%$ is considered to have good accuracy (Sablani; Baik; Marcotte, 2002).

$R_{a d j}^{2}=1-\left(1-R^{2}\right) \frac{a-1}{a-b}$

$M R E=\frac{100}{a} \sum_{i=1}^{a} \frac{\left|Y-Y^{*}\right|}{Y}$ 
In Equations 8 and 9, $Y$ is the experimental data, $Y^{*}$ is the calculated data from the regression, $b$ is the number of parameters in the model, $a$ is the number of experimental data points used in the regression analysis and $R^{2}$ is the coefficient of determination.

\section{RESULTS AND DISCUSSION}

\section{Experimental drying kinetics}

The time required to dry orange seeds from an initial moisture content of around $1.022 \mathrm{~kg} / \mathrm{kg}$, d.b. to the final moisture content of around $0.063 \mathrm{~kg} / \mathrm{kg}$, d.b. (all drying velocities) was $8640 \mathrm{~s}(2.4 \mathrm{~h}), 7200 \mathrm{~s}$ $(2.0 \mathrm{~h}), 5760 \mathrm{~s}(1.6 \mathrm{~h})$ and $5760 \mathrm{~s}(1.6 \mathrm{~h})$ at the drying temperatures of $40,50,60$ and $70{ }^{\circ} \mathrm{C}$, respectively. The time of drying for orange seeds was faster compared to other seeds such as grape seeds (4.6 h) (Roberts; Kidd; Padilla-Zakour, 2008), cuphea seeds (3.7 h) (Cermak et al., 2005) and amaranth seeds (3.1 h) (Abalone et al., 2006). Curves of moisture content versus drying time and the drying rate versus moisture content of orange seeds for the different drying air temperatures and velocities are shown in Figure 2.

In Figure 2, the moisture content reduces exponentially as the drying time increased. In these curves, an increase of drying rate, given by the curve slope, with increase in temperature was observed, being consistent with the reported in literature for this product (Roberts; Kidd; Padilla-Zakour, 2008; Kaleemullah; Kailappan, 2006). On the other hand, orange seeds did not exhibit a constant rate period of drying, observing only the falling rate period, behavior was also observed by Cantu-Lozano et al. (2013) in study with grapefruit seed. The drying rate was slightly more for oranges seeds dried at higher temperature than the orange seeds dried at lower temperatures for the same average moisture content. According to Kallemullah and Kailappan (2006) at higher temperatures the relative humidity of the drying air was less compared to drying air at lower temperatures. Because of this, the difference in the partial vapour pressure between orange seeds and the surrounding higher temperature drying air environment was more compared to the difference in partial vapour pressure between orange seeds and the surrounding lower temperature drying air environment. Hence, the moisture transfer rate was more with higher temperature drying air.

\section{Mathematical modelling of drying kinetics}

The three thin-layer models expressed by Equations 1 and 3 were applied to describe the drying kinetics of orange seeds through the fit to the experimental data.
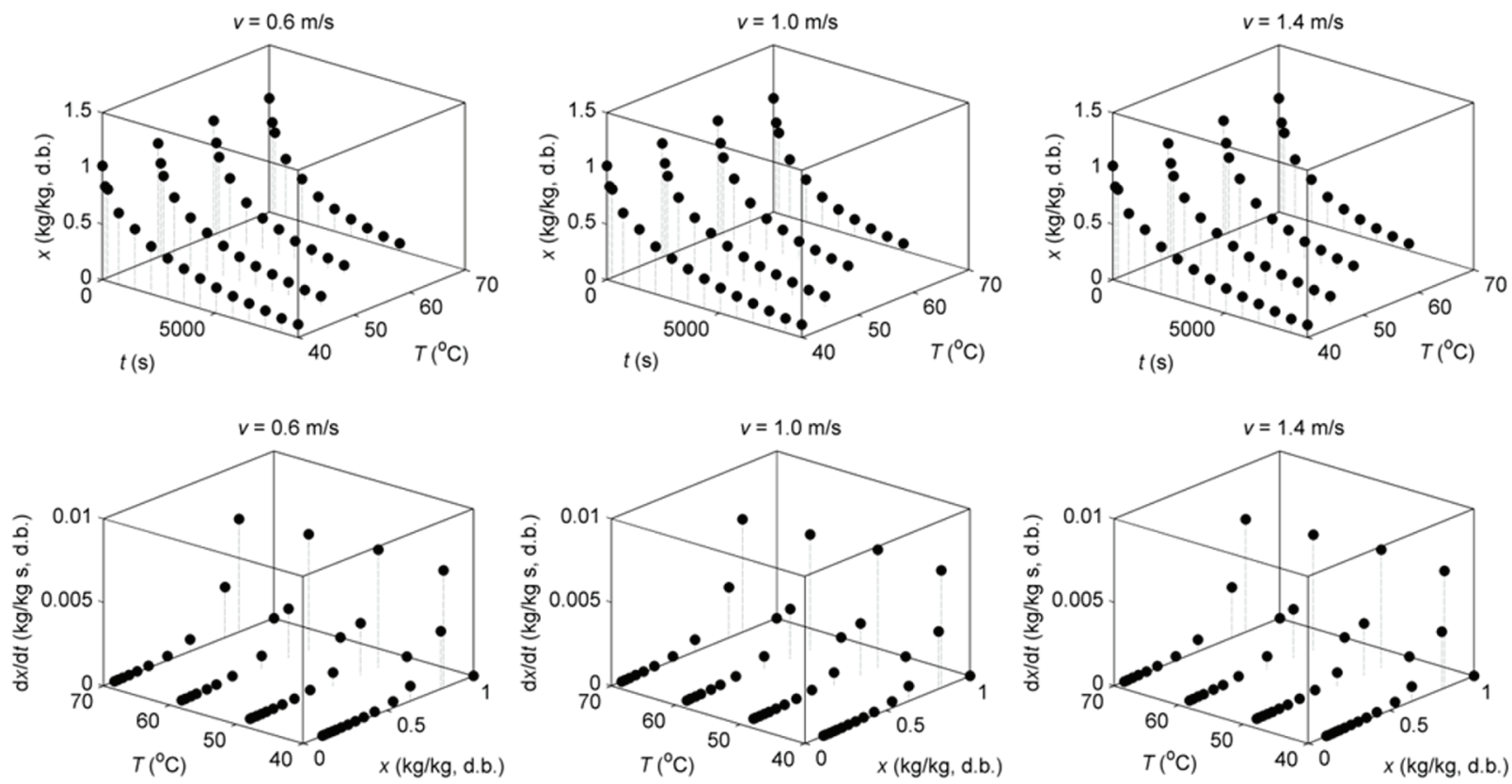

Figure 2: Moisture content versus drying time and drying rate $(\mathrm{d} x / \mathrm{d} t)$ versus moisture content for orange seeds at the different drying temperatures and velocities. 
The drying parameters $k$ and $\beta_{l}$ in Equation $1, k$ in Equation 2 , and $k$ and $\beta_{2}$ in Equation 3 were determined for each drying test. Modelling results and statistical validation are shown in Tables 1 and 3. There was an increased observed in Tables 2 and 3, increase of the parameter $k$ when the temperature increases for each drying velocity level. Already for the Page model (Table 1) close values of $k$ parameter were found.

In general terms, the three models presented similar behavior with respect to the temperature, being consistent with the reported by Roberts, Kidd and PadillaZakour (2008) for grape seeds, Doymaz (2007) for pumpkin slices and Dandamrongrak, Young and Mason (2002) for banana.
To assess the adequacy of each model, the $R_{a d j}^{2}$ and $M R E$ were used to compare the performance of the Page, Lewis and Henderson-Pabis models.

Results of $R_{a d j}^{2}$ (values above 0.960 ) showed a good assessment of the three models to represent the drying curves but, when the performance of the modelling was evaluated with the $M R E$, the Page and the Lewis model showed poor correlation between the experimental and calculated data (values above $15 \%$ ). Only the Henderson-Pabis model showed a good fitting result for both statistical terms $\left(R_{a d j}^{2}>0.978\right.$ and $M R E<$ $10.171 \%$ ). Closed curves between the experimental and calculated data using the Henderson-Pabis model can be observed in Figure 3.

Table 1: Parameter results of the thin-layer Page model.

\begin{tabular}{|c|c|c|c|c|c|c|}
\hline$v(\mathrm{~m} / \mathrm{s})$ & $T\left({ }^{\circ} \mathrm{C}\right)$ & Parameter & Value & C.I $(95 \%)$ & $R_{a d j}^{2}$ & $\operatorname{MRE}(\%)$ \\
\hline \multirow{8}{*}{0.6} & \multirow{2}{*}{40} & $k$ & 0.026 & $0.002-0.050$ & \multirow{2}{*}{0.961} & \multirow{2}{*}{14.605} \\
\hline & & $\beta_{1}$ & 0.516 & $0.397-0.634$ & & \\
\hline & \multirow{2}{*}{50} & $k$ & 0.019 & $0.005-0.034$ & \multirow{2}{*}{0.982} & \multirow{2}{*}{14.531} \\
\hline & & $\beta_{1}$ & 0.564 & $0.463-0.664$ & & \\
\hline & \multirow{2}{*}{60} & $k$ & 0.019 & $0.002-0.036$ & \multirow{2}{*}{0.982} & \multirow{2}{*}{16.658} \\
\hline & & $\beta_{1}$ & 0.584 & $0.462-0.706$ & & \\
\hline & \multirow{2}{*}{70} & $k$ & 0.018 & $0.003-0.034$ & \multirow{2}{*}{0.984} & \multirow{2}{*}{16.853} \\
\hline & & $\beta_{1}$ & 0.590 & $0.471-0.709$ & & \\
\hline \multirow{8}{*}{1.0} & \multirow{2}{*}{40} & $k$ & 0.026 & $0.002-0.050$ & \multirow{2}{*}{0.960} & \multirow{2}{*}{14.901} \\
\hline & & $\beta_{1}$ & 0.516 & $0.396-0.635$ & & \\
\hline & \multirow{2}{*}{50} & $k$ & 0.019 & $0.005-0.034$ & \multirow{2}{*}{0.982} & \multirow{2}{*}{14.651} \\
\hline & & $\beta_{1}$ & 0.564 & $0.464-0.665$ & & \\
\hline & \multirow{2}{*}{60} & $k$ & 0.023 & $-0.012-0.060$ & \multirow{2}{*}{0.985} & \multirow{2}{*}{29.937} \\
\hline & & $\beta_{1}$ & 0.542 & $0.414-0.671$ & & \\
\hline & \multirow{2}{*}{70} & $k$ & 0.018 & $0.003-0.034$ & \multirow{2}{*}{0.984} & \multirow{2}{*}{17.165} \\
\hline & & $\beta_{1}$ & 0.592 & $0.474-0.710$ & & \\
\hline \multirow{8}{*}{1.4} & \multirow{2}{*}{40} & $K$ & 0.026 & $0.001-0.050$ & \multirow{2}{*}{0.960} & \multirow{2}{*}{15.420} \\
\hline & & $\beta_{1}$ & 0.518 & $0.398-0.638$ & & \\
\hline & \multirow{2}{*}{50} & $K$ & 0.019 & $0.005-0.034$ & \multirow{2}{*}{0.982} & \multirow{2}{*}{14.741} \\
\hline & & $\beta_{1}$ & 0.564 & $0.464-0.665$ & & \\
\hline & 60 & $K$ & 0.019 & $0.002-0.035$ & 0983 & 17388 \\
\hline & 00 & $\beta_{1}$ & 0.588 & $0.468-0.709$ & 0.983 & 17.080 \\
\hline & 70 & $K$ & 0.018 & $0.003-0.033$ & 0985 & 17001 \\
\hline & 10 & $\beta_{1}$ & 0.592 & $0.476-0.708$ & 0.985 & 17.001 \\
\hline
\end{tabular}

$k$ : drying rate of Page model (1/s), $\beta$ : parameter of the Page model (dimensionless), $v$ : drying velocity $(\mathrm{m} / \mathrm{s})$, and C.I: confidence intervals of the fitting modelling $\alpha=95 \%$. 
Table 2: Parameter results of the thin-layer Lewis model.

\begin{tabular}{cccccc}
\hline$v(\mathrm{~m} / \mathrm{s})$ & $T\left({ }^{\circ} \mathrm{C}\right)$ & $k$ & C.I $(95 \%)$ & $R_{a d j}^{2}$ & MRE $(\%)$ \\
\hline \multirow{4}{*}{0.6} & 40 & $6.505 \times 10^{-4}$ & $4.246 \times 10^{-4}-8.765 \times 10^{-4}$ & 0.972 & 24.164 \\
& 50 & $7.906 \times 10^{-4}$ & $5.261 \times 10^{-4}-1.055 \times 10^{-3}$ & 0.977 & 26.254 \\
& 60 & $1.050 \times 10^{-3}$ & $6.565 \times 10^{-4}-1.444 \times 10^{-3}$ & 0.976 & 25.004 \\
& 70 & $1.075 \times 10^{-3}$ & $6.781 \times 10^{-4}-1.472 \times 10^{-3}$ & 0.976 & 25.110 \\
\hline \multirow{4}{*}{1.0} & 40 & $6.660 \times 10^{-4}$ & $4.293 \times 10^{-4}-8.908 \times 10^{-4}$ & 0.971 & 23.927 \\
& 50 & $7.942 \times 10^{-4}$ & $5.284 \times 10^{-4}-1.060 \times 10^{-3}$ & 0.977 & 26.182 \\
& 60 & $1.063 \times 10^{-3}$ & $6.664 \times 10^{-4}-1.459 \times 10^{-3}$ & 0.976 & 24.775 \\
& 70 & $1.094 \times 10^{-3}$ & $6.898 \times 10^{-4}-1.498 \times 10^{-3}$ & 0.976 & 25.250 \\
\hline \multirow{3}{*}{1.4} & 40 & $6.743 \times 10^{-4}$ & $4.375 \times 10^{-4}-9.111 \times 10^{-4}$ & 0.970 & 23.613 \\
& 50 & $7.950 \times 10^{-3}$ & $5.287 \times 10^{-4}-1.061 \times 10^{-3}$ & 0.977 & 26.173 \\
& 60 & $1.066 \times 10^{-3}$ & $6.704 \times 10^{-4}-1.461 \times 10^{-3}$ & 0.976 & 24.717 \\
& 70 & $1.074 \times 10^{-3}$ & $6.819 \times 10^{-4}-1.467 \times 10^{-3}$ & 0.976 & 25.214 \\
\hline
\end{tabular}

$k$ : drying rate of Lewis model (1/s), $v$ : drying velocity (m/s), and C.I: confidence intervals of the fitting modelling $\alpha=95 \%$.

According to Bonazzi, Broyart and Courtois (2009) the Henderson-Pabis model has been used extensively for characterizing thin layer drying of cereals, oilseeds, and ear corn, due to it kinetic parameter to represent the dependence between the moisture content and the air temperature $(T)$. In this case, the temperature dependence was observed with the linear increase of $k$ parameter with respect to the temperature (Table 3 ). Thus, this model is accepted to describe mathematically the relationship between the drying kinetic of orange seeds (moisture content and drying time) with a certain physical level.

For a better physical understanding of the mass transfer occurring in the drying process of orange seeds, the diffusive model (Equation 5) was employed. To implement the diffusive model, boundary conditions (described previously) and experimental conditions (Table 4) were applied. Although these conditions, the initial moisture content $\left(x_{i}=1.022 \mathrm{~kg} / \mathrm{kg}\right.$, d.b. $)$ and the average diameter $\left(d_{p}=8.30 \mathrm{~mm} ; r=4.15 \mathrm{~mm}\right)$, determined by sieve test at the moisture content level of $1.020 \mathrm{~kg} / \mathrm{kg}$, d.b., were kept constants in the modelling. Results of the fitting modeling with diffusive model are shown in Table 4.

In Table 5, the statistical values of $R_{a d j}^{2}>0.997$ and MRE $<11.920 \%$ show a good accuracy of the model prediction and the closeness between experimental and calculated data, respectively. Graphical representation of the accuracy of diffusive model as well as the residual analysis is shown in Figure 4.
Values of the effective moisture diffusivity $\left(D_{\text {eff }}\right)$ ranging from $4.960 \times 10^{-10}$ to $8.596 \times 10^{-10} \mathrm{~m} / \mathrm{s}^{2}$ in the temperature range of $40-70{ }^{\circ} \mathrm{C}$ and drying velocities of $0.6-1.4 \mathrm{~m} / \mathrm{s}$. Similar values were found in products such as grapefruit seeds (Cantú-Lozano et al., 2013) and grape seeds (Roberts; Kidd; Padilla-Zakour, 2008). Also, the $D_{\text {eff }}$ increase when the temperature increases for each drying velocity level.

The effective diffusivities depend on the drying air temperature besides variety and composition of material (Rizvi, 2005). According Kartika et al. (2012) the chemisorption on polar groups as the lipids and aromatic compounds can affect the effective moisture diffusivity. With increasing temperatures more hydrophilic sites increases and the migration of water from inside of orange seeds to the surface occurs. It also, was reported that at temperatures of $70{ }^{\circ} \mathrm{C}$ the heat of sorption decreased as the moisture content increased, reaching to the water vaporization energy at $x$ over $0.050 \mathrm{~kg} / \mathrm{kg}$, d.b. (Rosa; Villa-Vélez; Telis-Romero, 2013), value similar to obtained in the drying tests.

Moreover, the temperature dependence of the effective diffusivity has been shown to follow an Arrhenius relationship (Equation 7). Thus, plotting $\ln \left(D_{\text {eff }}\right)$ versus 1/T, values of the energy activation $\left(E_{a}\right)$ and pre-exponential factor of Arrhenius $\left(D_{0}\right)$ were calculated from the slope and intercept by a linear regression, respectively. Results of $E_{a}$ and corresponding to the drying velocities of 0.6, 1.0 and $1.4 \mathrm{~m} / \mathrm{s}$ were shown in Equations 10, 11 and 12, respectively. 
Table 3: Parameter results of the thin-layer Henderson-Pabis model.

\begin{tabular}{|c|c|c|c|c|c|c|}
\hline$v(\mathrm{~m} / \mathrm{s})$ & $T\left({ }^{\circ} \mathrm{C}\right)$ & Parameter & Value & C.I (95\%) & $R_{a d j}^{2}$ & $M R E(\%)$ \\
\hline \multirow{8}{*}{0.6} & \multirow{2}{*}{40} & $K$ & $4.087 \times 10^{-4}$ & $3.550 \times 10^{-4}-4.624 \times 10^{-4}$ & \multirow{2}{*}{0.982} & \multirow{2}{*}{6.512} \\
\hline & & $\beta_{2}$ & 0.723 & $0.679-0.767$ & & \\
\hline & \multirow{2}{*}{50} & $K$ & $5.337 \times 10^{-4}$ & $4.416 \times 10^{-4}-6.259 \times 10^{-4}$ & \multirow{2}{*}{0.978} & \multirow{2}{*}{8.358} \\
\hline & & $\beta_{2}$ & 0.776 & $0.718-0.835$ & & \\
\hline & \multirow{2}{*}{60} & $K$ & $7.011 \times 10^{-4}$ & $5.562 \times 10^{-4}-8.459 \times 10^{-4}$ & \multirow{2}{*}{0.978} & \multirow{2}{*}{9.482} \\
\hline & & $\beta_{2}$ & 0.787 & $0.721-0.854$ & & \\
\hline & \multirow{2}{*}{70} & $K$ & $7.219 \times 10^{-4}$ & $5.730 \times 10^{-4}-8.707 \times 10^{-4}$ & \multirow{2}{*}{0.979} & \multirow{2}{*}{9.926} \\
\hline & & $\beta_{2}$ & 0.791 & $0.726-0.857$ & & \\
\hline \multirow{8}{*}{1.0} & \multirow{2}{*}{40} & $K$ & $4.132 \times 10^{-4}$ & $3.587 \times 10^{-4}-4.676 \times 10^{-4}$ & \multirow{2}{*}{0.982} & \multirow{2}{*}{6.643} \\
\hline & & $\beta_{2}$ & 0.722 & $0.678-0.766$ & & \\
\hline & \multirow{2}{*}{50} & $K$ & $5.361 \times 10^{-4}$ & $4.435 \times 10^{-4}-6.286 \times 10^{-4}$ & \multirow{2}{*}{0.978} & \multirow{2}{*}{8.439} \\
\hline & & $\beta_{2}$ & 0.776 & $0.718-0.835$ & & \\
\hline & \multirow{2}{*}{60} & $K$ & $7.112 \times 10^{-4}$ & $5.631 \times 10^{-4}-8.593 \times 10^{-4}$ & \multirow{2}{*}{0.978} & \multirow{2}{*}{9.676} \\
\hline & & $\beta_{2}$ & 0.789 & $0.723-0.856$ & & \\
\hline & \multirow{2}{*}{70} & $K$ & $7.303 \times 10^{-4}$ & $5.789 \times 10^{-4}-8.172 \times 10^{-4}$ & \multirow{2}{*}{0.979} & \multirow{2}{*}{10.124} \\
\hline & & $\beta_{2}$ & 0.793 & $0.727-0.859$ & & \\
\hline \multirow{8}{*}{1.4} & \multirow{2}{*}{40} & $K$ & $4.213 \times 10^{-4}$ & $3.653 \times 10^{-4}-4.772 \times 10^{-4}$ & \multirow{2}{*}{0.982} & \multirow{2}{*}{6.805} \\
\hline & & $\beta_{2}$ & 0.722 & $0.678-0.766$ & & \\
\hline & \multirow{2}{*}{50} & $K$ & $5.364 \times 10^{-4}$ & $4.435 \times 10^{-4}-6.293 \times 10^{-4}$ & \multirow{2}{*}{0.978} & \multirow{2}{*}{8.426} \\
\hline & & $\beta_{2}$ & 0.776 & $0.718-0.835$ & & \\
\hline & 60 & $K$ & $7.152 \times 10^{-4}$ & $5.659 \times 10^{-4}-8.646 \times 10^{-4}$ & 0978 & 9727 \\
\hline & & $\beta_{2}$ & 0.791 & $0.724-0.858$ & & \\
\hline & 70 & $K$ & $7.257 \times 10^{-4}$ & $5.749 \times 10^{-4}-8.764 \times 10^{-4}$ & 0070 & 171 \\
\hline & 10 & $\beta_{2}$ & 0.794 & $0.728-0.861$ & 0.919 & $10.1 / 1$ \\
\hline
\end{tabular}

$k$ : drying rate of Henderson-Pabis model (1/s), $\beta_{2}$ : parameter of the Henderson-Pabis model (dimensionless), $v$ : drying velocity $(\mathrm{m} / \mathrm{s})$, and C.I: confidence intervals of the fitting modelling $\alpha=95 \%$.
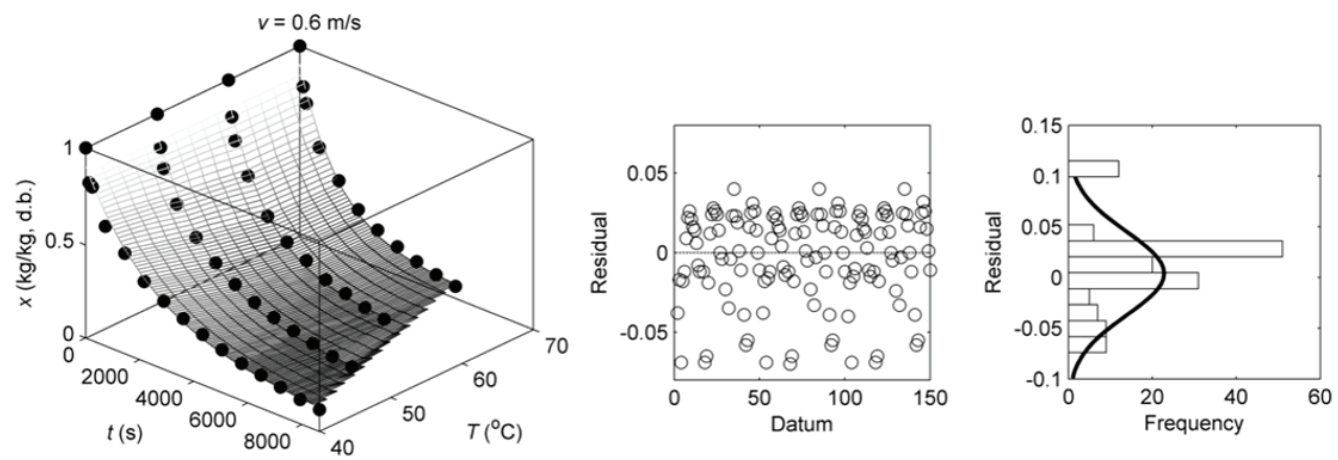

Figure 3: Dependence of the moisture content $(x)$ of orange seeds on time $(t)$ and on temperature $(T)$, and graphical residual analysis between experimental $x$ and $x$ calculated by Henderson-Pabis model. 
Table 4: Experimental conditions of drying for diffusive model application.

\begin{tabular}{ccccc}
\hline$v(\mathrm{~m} / \mathrm{s})$ & $T\left({ }^{\circ} \mathrm{C}\right)$ & $R H(\%)$ & $a_{w}$ & $x_{e}$ \\
\hline \multirow{3}{*}{0.6} & 40 & 11.9 & 0.119 & 0.105 \\
& 50 & 11.3 & 0.113 & 0.068 \\
& 60 & 11.0 & 0.110 & 0.066 \\
& 70 & 10.6 & 0.106 & 0.063 \\
\hline \multirow{3}{*}{1.0} & 40 & 11.7 & 0.117 & 0.106 \\
& 50 & 11.0 & 0.110 & 0.068 \\
& 60 & 10.8 & 0.108 & 0.065 \\
& 70 & 10.4 & 0.104 & 0.062 \\
\hline \multirow{3}{*}{1.4} & 40 & 11.5 & 0.115 & 0.106 \\
& 50 & 11.0 & 0.110 & 0.068 \\
& 60 & 10.3 & 0.103 & 0.064 \\
& 70 & 10.1 & 0.101 & 0.061 \\
\hline
\end{tabular}

$v$ : drying velocity $(\mathrm{m} / \mathrm{s}), \mathrm{RH}$ : relative humidity of air drying, $a_{w}:$ water activity and $x_{e}$ : calculated equilibrium moisture content from Oswin model ( $\mathrm{kg} / \mathrm{kg}$, d.b.).

Table 5: Effective diffusive coefficient results of drying kinetics of orange seeds.

\begin{tabular}{cccccc}
\hline$v(\mathrm{~m} / \mathrm{s})$ & $T\left({ }^{\circ} \mathrm{C}\right)$ & $D\left(\mathrm{~m} / \mathrm{s}^{2}\right)$ & C.I $(95 \%)$ & $R^{2}$ & $M R E(\%)$ \\
\hline \multirow{4}{*}{0.6} & 40 & $4.960 \times 10^{-10}$ & $4.520 \times 10^{-10}-5.401 \times 10^{-10}$ & 0.997 & 8.015 \\
& 50 & $6.448 \times 10^{-10}$ & $5.931 \times 10^{-10}-6.965 \times 10^{-10}$ & 0.999 & 7.993 \\
& 60 & $8.248 \times 10^{-10}$ & $7.312 \times 10^{-10}-9.184 \times 10^{-10}$ & 0.998 & 10.804 \\
& 70 & $8.503 \times 10^{-10}$ & $7.572 \times 10^{-10}-9.435 \times 10^{-10}$ & 0.999 & 11.643 \\
\hline \multirow{4}{*}{1.0} & 40 & $5.015 \times 10^{-10}$ & $4.563 \times 10^{-10}-5.468 \times 10^{-10}$ & 0.997 & 8.256 \\
& 50 & $6.475 \times 10^{-10}$ & $5.953 \times 10^{-10}-6.998 \times 10^{-10}$ & 0.998 & 8.107 \\
& 60 & $8.363 \times 10^{-10}$ & $7.402 \times 10^{-10}-9.325 \times 10^{-10}$ & 0.998 & 11.300 \\
& 70 & $8.596 \times 10^{-10}$ & $7.654 \times 10^{-10}-9.539 \times 10^{-10}$ & 0.999 & 11.920 \\
\hline \multirow{4}{*}{1.4} & 40 & $5.120 \times 10^{-10}$ & $4.649 \times 10^{-10}-5.592 \times 10^{-10}$ & 0.997 & 8.693 \\
& 50 & $6.481 \times 10^{-10}$ & $5.956 \times 10^{-10}-7.005 \times 10^{-10}$ & 0.998 & 8.169 \\
& 60 & $8.410 \times 10^{-10}$ & $7.445 \times 10^{-10}-9.376 \times 10^{-10}$ & 0.998 & 11.454 \\
& 70 & $8.548 \times 10^{-10}$ & $7.621 \times 10^{-10}-9.475 \times 10^{-10}$ & 0.999 & 11.675 \\
\hline$D_{\text {eff }}:$ effective moisture diffusivity $\left(\mathrm{m}^{2} / \mathrm{s}\right), v:$ drying velocity $(\mathrm{m} / \mathrm{s})$, and C.I: confidence intervals of the fitting modelling $\alpha=95 \%$.
\end{tabular}

$D_{\text {eff }}=3.229 \times 10^{-7} \exp \left(\frac{-16762.2}{R T}\right)$

$D_{\text {eff }}=3.359 \times 10^{-7} \exp \left(\frac{-16842.2}{R T}\right)$

$D_{\text {eff }}=2.643 \times 10^{-7} \exp \left(\frac{-16174.1}{R T}\right)$
The equations above showed values of $R_{a d j}^{2}=$ 0.965 for $v=0.6 \mathrm{~m} / \mathrm{s}, R_{a d j}^{2}=0.964$ for $v=1.0 \mathrm{~m} / \mathrm{s}$ and $R^{2}{ }_{a d j}=0.961$ for $v=1.4 \mathrm{~m} / \mathrm{s}$, since that the closeness of $E_{a}$ values showed a poor influence of the drying velocity on the process. $E_{a}$ results were similar to the reported by Roberts, Kidd and Padilla-Zakour (2008) for different varieties of grape seeds and CantúLozano et al. (2013) for grapefruit seeds at different air velocities.

Ciênc. Agrotec., Lavras, v.39, n.3, p.291-300, maio/jun., 2015 

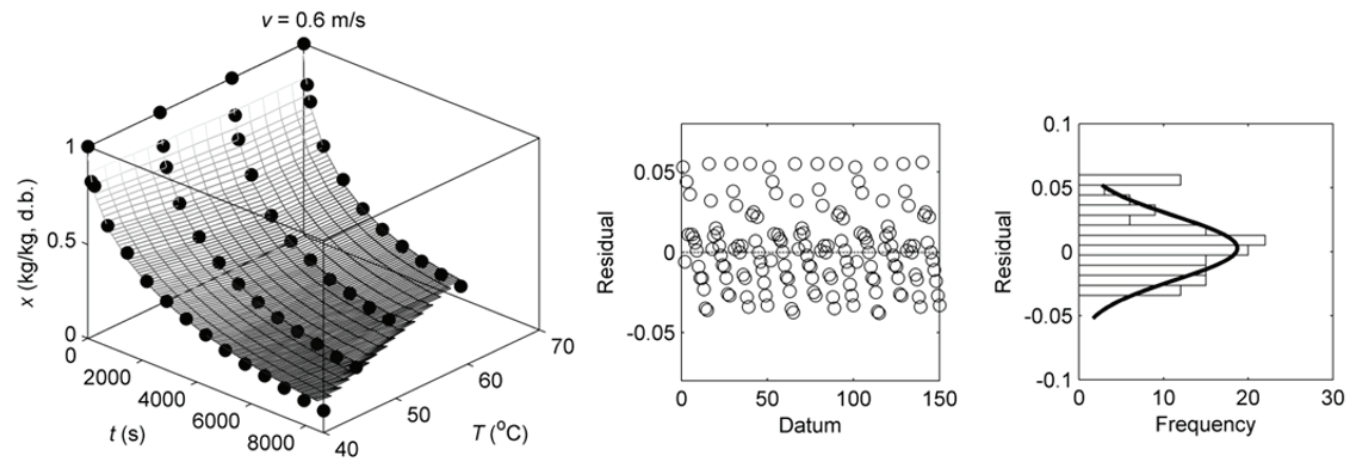

Figure 4: Dependence of the moisture content $(x)$ of orange seeds on time $(t)$ and on temperature $(T)$, and graphical residual analysis between experimental $x$ and $x$ calculated by diffusive model.

\section{CONCLUSIONS}

Experimental drying kinetics of orange seeds was carried out at temperatures of $40-70{ }^{\circ} \mathrm{C}$ and drying velocities of $0.6,1.0$ and $1.4 \mathrm{~m} / \mathrm{s}$. Three thin-layers models (Page, Lewis and Henderson-Pabis) and the diffusive model (spherical coordinate) were employed to fit the drying curves. Statistical results showed the HendersonPabis model as the best thin-layer model to represent the drying kinetic of orange seeds $\left(R_{a d j}^{2}>0.978\right)$. Moreover, the diffusive model presented good performance $\left(R_{a d j}^{2}>\right.$ $0.997)$ to describe the mass transfer process occurring in the drying of orange seeds. Values of the effective moisture diffusivity ranging from $4.960 \times 10^{-10}$ to $8.596 \times 10^{-10} \mathrm{~m} / \mathrm{s}^{2}$ in the temperature range of $40-70^{\circ} \mathrm{C}$ and drying velocities of $0.6-1.4 \mathrm{~m} / \mathrm{s}$. Finally, the temperature dependence of the effective diffusivity showed an Arrhenius relationship, where the activation energy was determined observing poor influence by the drying velocity in the process.

\section{ACKNOWLEDGEMENT}

The authors gratefully acknowledge the financial support received from FAPESP (Process Number 2009/11675-3).

\section{REFERENCES}

ABALONE, R. et al. Thin layer drying of amaranth seeds. Biosystems Engineering. 93(2):179-188, 2006.

\section{ASSOCIATION OF ANALYTICAL COMMUNITIES} - AOAC. Official methods of analysis, Gaithersburg. AOAC International. 1997.

BARATI, E.; ESFAHANI, J.A. A new solution approach for simultaneous heat and mass transfer during convective drying of mango. Journal of Food Engineering. 102(4):302-309, 2011.

BONAZZI, C.; BROYART, B.; COURTOIS, F. Dryer modeling. In: RATTI, C. Advances in food dehydration. New York: Taylor \& Francis Group, 2009. p. 1-488.

BROVCHENKO, I.; OLEINIKOVA, A.

Interfacial and confined water. Oxford: Elsevier, 2008. 317 p.

CANTU-LOZANO, D. et al. Sorption isotherms and drying kinetics of grapefruit seeds. Acta Scientiarum. Technology. 35(4):717-723, 2013.

CERMAK, S.C. et al. Batch drying of cuphea seeds. Industrial Crops and Products. 21(3):353-359, 2005.

CRANK, J. The mathematics of diffusion. London: Oxford University Press, 1975. 1 p.

DANDAMRONGRAK, R.; YOUNG, G.; MASON, R. Evaluation of various pre-treatments for the dehydration of banana and selection of suitable drying models. Journal of Food Engineering. 55(2):139146, 2002.

DOIJODE, S.D. Seed Storage of Horticultural Crops. New York: Food Products Press, 2001. 357 p.

DOYMAZ, Í. The kinetics of forced convective air-drying of pumpkin slices. Journal of Food Engineering. 79(1):243-248, 2007. 
EL-ADAWY, T.A.; TAHA, K.M. Characteristics and composition of different seed oils and flours. Food Chemistry. 74(1):47-54, 2001.

KALEEMULLAH, S.; KAILAPPAN, R. Modelling of thin-layer drying kinetics of red chillies. Journal of Food Engineering. 76(4):531-537, 2006.

KARTIKA, I.A. et al. Moisture sorption behaviour of jatropha seeds (Jatropha curcas) as a source of vegetable oil biodiesel production. Biomass and Bioenergy. 36(2012):226-233, 2012.

LOPEZ, A. et al. Thin-layer drying behavior of vegetable wastes from wholesale market. Drying Technology. 18(4-5):995-1006, 2000.

NICOLETI, J.F.; TELIS-ROMERO, J.; TELIS, V.R.N. Air-drying of fresh and osmotically pretreated pineapple slices: fixed air temperature versus fixed slice temperature drying kinetics. Drying Technology. 19(9):2175-2191, 2001.

RIZVI, S.S.H. Thermodynamic Properties of Foods in Dehydration. In: RAO, M.A.; RIZVI, S.S.H.; DATTA, A.K. Engineering Properties of Foods. Boca Raton: Taylor \& Francis Group, p. 1-88. 2005.
ROBERTS, J.S.; KIDD, D.R.; PADILLA-ZAKOUR, O. Drying kinetics of grape seeds. Journal of Food Engineering. 89(4):460-465, 2008.

ROSA, D.P.; VILLA-VÉLEZ, H.A.; TELIS-ROMERO, J. Study of the enthalpy-entropy mechanism from water sorption of orange seeds (C. sinensis $c v$. Brazilian) for the use of agro-industrial residues as a possible source of vegetable oil production. Ciência e Tecnologia de Alimentos. 33:95-101, 2013.

SABLANI, S.; RAHMAN, S.; AL-HABSI, N. Moisture diffusivity in foods. An overview. In: MUJUMDAR, A.S. Drying technology in agriculture and food sciences. Enfield: Science Publishers, Inc, 2000 .

SABLANI, S.S.; BAIK, O.D.; MARCOTTE, M. Neural networks for predicting thermal conductivity of bakery products. Journal of Food Engineering. 52(3):299304, 2002.

VEGA-GÁLVEZ, A. et al. Effective moisture diffusivity determination and mathematical modelling of the drying curves of the olive-waste cake. Bioresource Technology. 101(19):7265-7270, 2010 . 